\title{
Situs inversus totalis with carcinoma of gastric cardia: a case report
}

\author{
Pan Ke, Zhong Dewu, Miao Xiongying, Liu Guoqing*, Jiang Qunguang and Liu Yi
}

\begin{abstract}
Situs inversus is an uncommon anomaly with rare incidence. Some cases of situs inversus totalis have been described with different types of associations. Here we report a case of situs inversus with carcinoma of the gastric cardia.
\end{abstract}

Keywords: Situs inversus, Carcinoma of the gastric cardia, Case report

\section{Background}

Situs inversus is an uncommon anomaly with an incidence varying from 1 in 4,000 to 1 in 20,000 live births [1], with a male:female ratio of 3:2 [2]. Situs inversus viscerum can be either total or partial. Total situs inversus can be called a mirror image dextrocardia, characterized by a heart and stomach at the right side of the midline while the liver and gall bladder are at the left side. Although this does not seem to affect normal health or life expectancy, situs inversus viscerum only does not affect the patient's health when it is premalignant. Generally, this rare genetic anomaly is discovered or diagnosed incidentally during thoracic and abdominal imaging. The exact etiology of situs inversus is still unknown, but an autosomal recessive inheritance mode has been speculated [3]. Some cases of situs inversus totalis have been described in previous studies [2,4-8]. We here report a case of situs inversus with carcinoma of the gastric cardia.

\section{Case presentation}

A 52-year-old male patient, who complained of a stomachache lasting over the last 5 months, along with the symptoms of fatigue and weight loss, was referred to our clinic. An abnormal shadow in the cardia was recognized during routine $\mathrm{X}$-ray examination and an upper gastrointestinal endoscopic examination. Upon admission, a physical examination revealed a pulse rate of 100 beats per minute and blood pressure of $115 / 68 \mathrm{mmHg}$, while the liver, spleen, and tumor were not palpable in the

\footnotetext{
* Correspondence: panke_liu@163.com

Department of General Surgery, Xiang-Ya 2nd Hospital, Central South University, Chang-Sha, Hunan Province, China
}

physical examination. Results of chest X-ray imaging taken in an erect position showed dextrocardia, a fundic gas shadow on the right dome of the diaphragm, and a liver shadow at the left side. Nothing abnormal was found in the respiratory system.

The laboratory findings were hemoglobin $11 \mathrm{~g} / \mathrm{dl}$ and white blood cells $6,500 / \mathrm{m}^{3}$. Dextrocardia was seen on the chest X-ray (Figure 1), and a typical congenital dextrocardia was found on the electrocardiographic findings. The endoscopic examination identified a tumor in the gastric cardia. The pathological diagnosis was moderately differentiated and partly poorly differentiated adenocarcinoma. Surgery was performed on 25 July 2011, and macroscopic metastasis was found in lymph nodes 1, 2, 3, 7, 8a, and 8p (for the numbering rules, see [9]). The operative procedure was Billroth I reconstruction and proximal gastrectomy with D2 lymph node discectomy. The macroscopic findings of the resected specimen showed irregularly shaped gastric cardia of $20 \mathrm{~mm} \times 18 \mathrm{~mm}$ size. The histological finding showed proliferation of moderately and poorly differentiated tubular adenocarcinoma, positive lymph vessels, and venous invasion. This was a type I adenocarcinoma of the esophagogastric junction (AEG) [10]. Metastases were recognized in lymph nodes 1,3 , and $8 \mathrm{p}$ in the sentinel lymph node biopsy. The patient's postoperative course was uneventful; on day 15 after surgery, the patient was discharged from the hospital and commenced chemotherapy.

\section{Discussion}

Situs inversus is a positional anomaly that rotates the viscera of the internal abdomen, and it is a rare congenital 


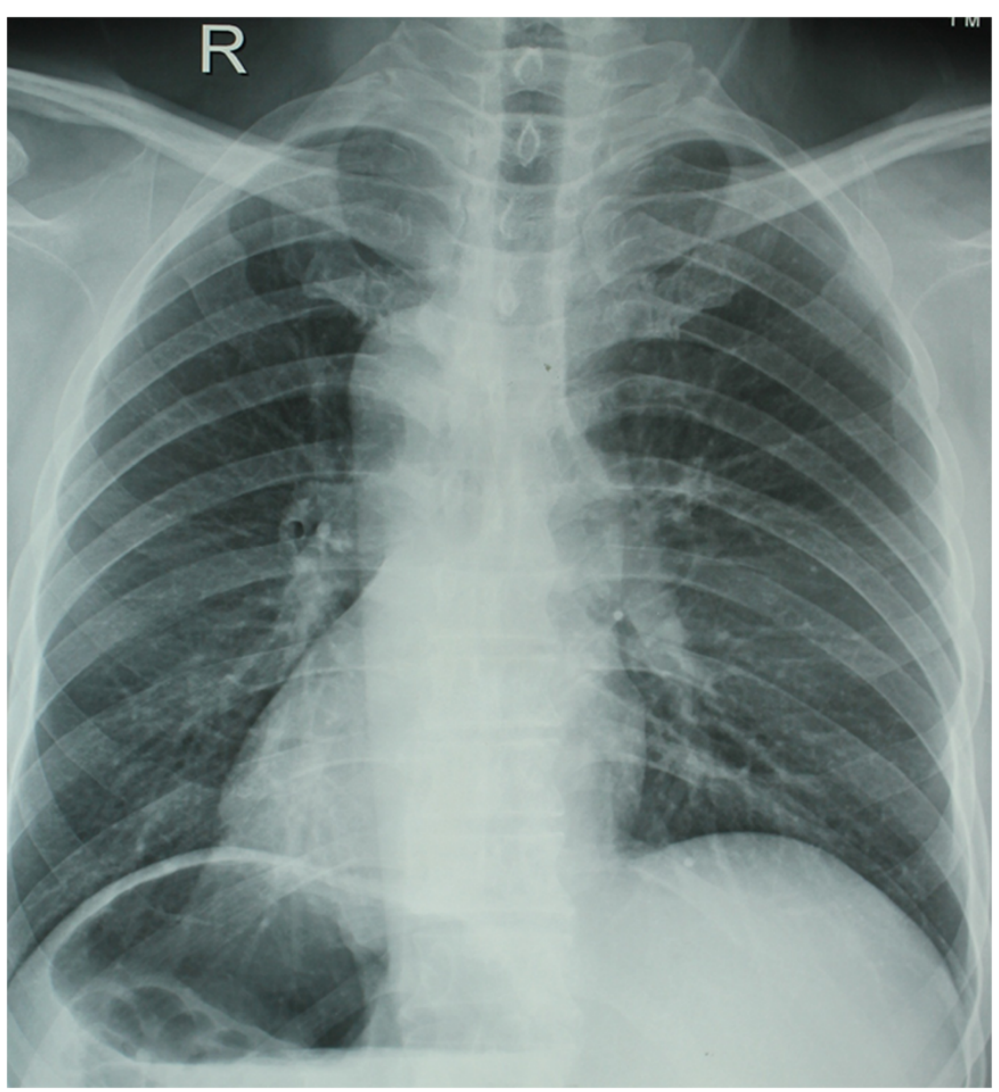

Figure 1 Chest X-ray demonstrating dextrocardia.

anomaly with a population incidence of only $0.001 \%$ to $0.01 \%$ [11]. It is suggested that the immobility of nodal cilia inhibits the flow of extra-embryonic fluid during the embryonic period, and this leads to the development of situs inversus [12]. Its transmission mode is autosomal recessive inheritance, but its precise genetic mechanism is still unidentified. More than one genetic mutation including the gene mutations that cause ciliopathy and cystic renal diseases has been implicated in the etiopathogenesis. Various modalities can be used to diagnose situs inversus, such as electrocardiograms, radiographic studies, and computed tomography (CT) scans with oral and intravenous contrast, ultrasound, and barium studies [11,13].

There have been isolated reports of situs inversus associated with peptic conditions [14], ulcer perforation [15], amoebic liver abscess [8], acute cholecystitis [7,16], cholelithiasis $[6,17,18]$, acute appendicitis $[4,19]$, and intestinal obstruction [20]. The occurrence of carcinoma of the gastric cardia with situs inversus is very rare, and very few cases have been reported in the literature [5,21-24]. There are no data on the relationship between gastric cancer and situs inversus totalis. It is very important to carry out a careful and cautious assessment of abnormalities by preoperative examination, especially by laparoscopic procedures.

\section{Conclusion}

The occurrence of gastric cardia with situs inversus is very rare. Proximal gastrectomy with lymph node dissection (D2) is the preferred operation for carcinoma of gastric cardia. Chemotherapy is essential for patients with lymph node metastasis.

\section{Consent}

Written informed consent was obtained from our patient for publication of this case report and all accompanying images.

\section{Competing interest}

The authors declare that they have no competing interests.

\section{Authors' contributions}

$\mathrm{PK}, \mathrm{ZD}, \mathrm{MX}, \mathrm{LG}, J \mathrm{Q}$ and $\mathrm{LY}$ designed the study, performed the data analysis and wrote the paper together; all authors read and approved the final manuscript.

Received: 2 July 2012 Accepted: 26 November 2012

Published: 11 December 2012

\section{References}

1. Budhiraja S, Singh G, Miglani HP, Mitra SK: Neonatal intestinal obstruction with isolated levocardia. J Pediatr Surg 2000, 35(7):1115-1116.

2. Huang SM, Yao CC, Tsai TP, Hsu GW: Acute appendicitis in situs inversus totalis. J Am Coll Surg 2008, 207(6):954. 
3. Djohan RS, Rodriguez HE, Wiesman IM, Unti JA, Podbielski FJ: Laparoscopic cholecystectomy and appendectomy in situs inversus totalis. Js/s 2000, 4(3):251-254.

4. Akbulut S, Caliskan A, Ekin A, Yagmur Y: Left-sided acute appendicitis with situs inversus totalis: review of 63 published cases and report of two cases. J Gastrointest Surg 2010, 14(9):1422-1428.

5. Benjelloun el B, Zahid FE, Ousadden A, Mazaz K, Ait Taleb K: A case of gastric cancer associated to situs inversus totalis. Cases J 2008, 1(1):391.

6. Pathak KA, Khanna R, Khanna NN: Situs inversus with cholelithiasis. J Postgrad Med 1995, 41(2):45-46.

7. Moreno AJ, Toney MA, Henry CD, Rodriguez AA, Turnbull GL: Acute cholecystitis in a patient with situs inversus. Clin Nucl Med 1990, 15(5):350-351.

8. Ansari ZA, Skaria J, Gopal MS, Vaish SK, Rai AN: Situs inversus with amoebic liver abscess. J Trop Med Hyg 1973, 76(7):169-170.

9. Tamura S, Takeno A, Miki H: Lymph node dissection in curative gastrectomy for advanced gastric cancer. Int I Surg Oncol 2011, 2011:748745.

10. Stein HJ, Feith M, Siewert JR: Cancer of the esophagogastric junction. Surg Oncol 2000, 9(1):35-41.

11. Nelson MJ, Pesola GR: Left lower quadrant pain of unusual cause. J Emerg Med 2001, 20(3):241-245.

12. Nonaka S, Tanaka Y, Okada Y, Takeda S, Harada A, Kanai Y, Kido M, Hirokawa $\mathrm{N}$ : Randomization of left-right asymmetry due to loss of nodal cilia generating leftward flow of extraembryonic fluid in mice lacking KIF3B motor protein. Cell 1998, 95(6):829-837.

13. Ratani RS, Haller JO, Wang WY, Yang DC: Role of CT in left-sided acute appendicitis: case report. Abdom Imaging 2002, 27(1):18-19.

14. Zaporozhets VK, Chupryna W, Vasilenko NI, Mal'ko VI: Peptic ulcer associated with complete situs inversus viscerum. Klin Med (Mosk) 1980, 58(3):95-96.

15. Gandhi DM, Warty PP, Pinto AC, Shetty SV: Perforated DU with dextrocardia and situs inversus. J Postarad Med 1986, 32:45-46.

16. Heimann T, Sicular A: Acute cholecystitis with situs inversus. N Y State J Med 1979, 79(2):253-254

17. de Campos Martins MV, Pantaleao Falcao JL, Skinovsky J, de Faria GM: Single-port cholecystectomy in a patient with situs inversus totalis presenting with cholelithiasis: a case report. J Med Case Rep 2012, 6:96.

18. McFarland SB: Situs inversus with cholelithiasis: a case report. J Tenn Med Assoc 1989, 82(2):69-70.

19. Seifmanesh H, Jamshidi K, Kordjamshidi A, Delpisheh A, Peyman H, Yasemi M: Acute left-sided appendicitis with situs inversus totalis: a case report. Am J Emerg Med 2010, 28(9):1058. e1055-1057.

20. Ruben GD, Templeton JM Jr, Ziegler MM: Situs inversus: the complex inducing neonatal intestinal obstruction. J Pediatr Surg 1983, 18(6):751-756.

21. Kim HB, Lee JH, Park do J, Lee HJ, Kim HH, Yang HK: Robot-assisted distal gastrectomy for gastric cancer in a situs inversus totalis patient. J Korean Surg Soc 2012, 82(5):321-324.

22. Seo KW, Yoon KY: Laparoscopy-assisted distal gastrectomy for early gastric cancer and laparoscopic cholecystectomy for gallstone with situs inversus totalis: a case report. J Korean Surg Soc 2011, 81(Suppl 1):S34-38.

23. Yamaguchi S, Orita H, Yamaoka T, Mii S, Sakata H, Hashizume M: Laparoscope-assisted distal gastrectomy for early gastric cancer in a 76year-old man with situs inversus totalis. Surg Endosc 2003, 17(2):352-353.

24. Yoshida Y, Saku M, Masuda Y, Maekawa S, Ikejiri K, Furuyama M: Total gastrectomy for gastric cancer associated with situs inversus totalis. A report of 2 cases. S Afr J Surg 1992, 30(4):156-158.

doi:10.1186/1477-7819-10-263

Cite this article as: Ke et al: Situs inversus totalis with carcinoma of gastric cardia: a case report. World Journal of Surgical Oncology 2012 10:263.

\section{Submit your next manuscript to BioMed Central and take full advantage of:}

- Convenient online submission

- Thorough peer review

- No space constraints or color figure charges

- Immediate publication on acceptance

- Inclusion in PubMed, CAS, Scopus and Google Scholar

- Research which is freely available for redistribution 